\title{
Rediscovering the King of Woodpeckers: Exploring the Implications
}

\section{La redécouverte du roi des pics : réflexion sur les implications}

\author{
$\underline{\text { Jeffrey R. Walters }}^{1}$ and Eileen L. Crist ${ }^{1}$
}

\begin{abstract}
The Ivory-billed Woodpecker has long held a special place in the psyche of North American conservation, eliciting unusually colorful prose, even from scientists, as an icon of the wild. The reverence in which it was held did little to slow the habitat loss that led to its apparent extinction 60 years ago. A consequence of the emotion and attention associated with the amazing rediscovery of this species is that conservation biologists will be under considerable pressure to make good on this "second chance." This poses a challenge to conservation paradigms that has important political consequences. First, the decline of the species is due to habitat loss, recovery from which has been much more seldom achieved than recovery from declines due to impacts on vital rates. This challenge is exacerbated by the enormous area requirements of the species. Second, the species at best exists as a critically small population. It will be difficult to make the case that a viable population can be established without undermining the small population paradigm that underlies conservation strategies for many other species. This has already resulted in some political backlash. Conservation of this species is best based on the one point of clear scientific consensus, that habitat is limiting, but this may result in additional political backlash because of conflicts with other land uses.
\end{abstract}

RÉSUMÉ. Le Pic à bec ivoire occupe depuis très longtemps une place privilégiée dans l'esprit du mouvement de conservation nord-américain et il suscite une prose particulièrement colorée, même chez les scientifiques, en tant que symbole des régions sauvages. La vénération qu'on lui accordait n'a pas fait grand chose pour ralentir la perte d'habitat qui a mené à son extinction apparente il y a 60 ans. Les émotions et l'attention suscitées par l'extraordinaire redécouverte de cette espèce auront pour conséquence d'exercer une pression considérable sur les biologistes en conservation afin qu'ils tirent parti de cette «deuxième chance». Ceci représente un défi pour les paradigmes de conservation dont les conséquences politiques sont majeures. Premièrement, le déclin de cette espèce a été causé par la perte d'habitat et le rétablissement d'espèces dont le déclin était relié à ce facteur a été beaucoup plus rarement réussi que lorsque le déclin était attribuable à des facteurs affectant leurs paramètres démographiques. Dans ce cas-ci, le défi est d'autant plus grand car le domaine vital de l'espèce est immense. Deuxièmement, la population de l'espèce est, au mieux, dangereusement réduite. Il sera difficile de soutenir qu'une population viable puisse être atteinte sans remettre en doute le paradigme des petites populations qui sous-tend les stratégies de conservation de nombreuses autres espèces. Ceci a déjà entraîné quelques contrecoups politiques. La conservation de cette espèce devrait être fondée sur le point faisant l'objet d'un consensus scientifique solide, i.e. que l'habitat est le facteur limitant. Toutefois, ceci pourrait aussi engendrer des contrecoups politiques additionnels à cause des conflits avec d'autres utilisations des terres.

Key Words: conservation paradigms; Ivory-billed Woodpecker; political backlash; population dynamics

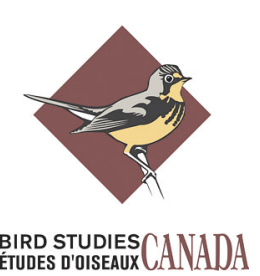


This majestic and formidable species...seeks the most towering trees of the forest; seeming particularly attached to those prodigious cypress swamps, whose crowded giant sons stretch their bare and blasted or moss-hung arms midway to the skies. In these almost inaccessible places, amid ruinous piles of impending timber, his trumpet-like note and loud strokes resound through the solitary, savage wilds, of which he seems sole lord and inhabitant. - Alexander Wilson (1840)

\section{INTRODUCTION}

Discovering the Ivory-billed Woodpecker (Campephilus principalis) in the bottomland forests of southeastern Arkansas (Fitzpatrick et al. 2005), 60 years after the last confirmed sighting on the North American mainland, has evoked more widespread excitement in the United States than any other conservation story-indeed perhaps any other science story-in recent memory. Now that the furor has subsided, it is appropriate to consider the realities of the situation. The emotion and exposure associated with the Ivory-billed Woodpecker's plight guarantees that it will impact conservation in the United States, and perhaps elsewhere, far more than will any other single species in the foreseeable future. Here, we provide some cultural and historical background, and explore the biological and political implications of its rediscovery (see also Koenig 2005).

\section{THE BIRD THAT BECAME LEGEND}

How anything looms in the cultural landscape is often revealed in the ways it is named. The hold of the Ivory-billed Woodpecker on American culture is intimated in the numerous names applied to it. The "Lord God bird" and "King of the Woodpeckers" are the most dramatic of its monikers. How admired these birds were is also readily evident in $18^{\text {th }}$ and $19^{\text {th }}$ century naturalist literature, which abounds in evocative depictions. Scientists as well, although trained to avoid colorful vocabulary, were unable to resist rich language when discussing the Ivory-billed Woodpecker. A cursory selection of descriptions yields expressions like "splendid," "astonishing," "strikingly handsome," "magnificent," and "stunningly beautiful." James Tanner praised the Ivory-bill as "dweller of treetops and sunshine... a handsome, vigorous, graceful bird" (quoted in Hoose 2004:101).
Its striking appearance and size, along with its predilection for ancient, inaccessible forests, have made the Ivory-billed Woodpecker an icon of North American wilderness. Aldo Leopold (1936) opined that the species is "a bird inextricably interwoven with our pioneer tradition-the very spirit of that 'dark and bloody' ground which has become the locus of our national culture."

\section{THE PATH TOWARD EXTINCTION}

The reverence in which the species was held was of little consequence the first time the Ivory-billed Woodpecker was faced with extinction. The decimation of the species resulted from the destruction of the virgin forests that were its habitat. In region after region, Tanner (1942:19) mapped the years of logging with those of population losses, showing that "the time of the Ivory-bill's disappearance from all or most of its former range coincided at least roughly with a time of active or rapidly increasing logging." "We have lost, or almost lost, the Ivory-billed Woodpecker," Jackson (2004:44) states succinctly, "because we neglected to respect its home."

By the end of the $19^{\text {th }}$ century, it was no secret that Ivory-billed Woodpeckers were extinction bound, and it is a sad fact that little was done to save them. Instead, the more rare they became, the more valuable did they loom in museum collections. Logging, moreover, continued unabated. It was only when the species was rediscovered by Tanner, after many thought it already extinct, that an attempt was made to save the Ivory-bill, in its last stronghold, the Singer tract. In 1940, Audubon's president John Baker took appeals from Tanner, Leopold (1936) and others to protect the woodpecker to the level of political action. He convinced Louisiana politicians to propose a bill for the creation of the Tensas Swamp National Park, and wrote to President Franklin Roosevelt to support the bill. Had the park been created, it would have protected the 60000 remaining acres of the Singer tract. After the bombing of Pearl Harbor, however, the proposal fell by the wayside. Chicago Mill and Lumber built a box factory in Tallulah, Louisiana, a few miles from the Singer tract, and proceeded, without remorse about the consequences to the woodpeckers (Koenig 2005), to make boxes for equipment, ammunition, weapons, food, provisions, and even tea for the English army, out of its trees. 
What is tragic about the first attempt to save the Ivory-billed Woodpecker is that the forest where the birds lived was cut despite the joint protests of biologists and the Audubon society, and in full knowledge that the species was being driven to extinction. As Mark Barrow (unpublished manuscript) states, "hopes for saving the Ivorybilled Woodpecker were dashed on the hard rocks of political and economic reality. Clearly science could reveal information about the status and ecology of this magnificent creature, but science alone could not effect the fundamental reorientation in values needed to save it." Ironically, where the Singer tract once stood, the 64 000-acre Tensas River National Wildlife Refuge was established in 1980, too late for the giant trees, the Ivory-billed Woodpecker, and other biota (Jackson 2004:151).

\section{A SECOND CHANCE: A CHALLENGE TO CONSERVATION PARADIGMS}

The species reemerged not in the Tensas River NWR, but across the border in the Big Woods of Arkansas. Seventy years have intervened between the Louisiana and Arkansas discoveries, yet the news has the same exhilarating and urgent ring: the species is not extinct but on the brink, giving immediate rise to a conservation mandate. Can we succeed where we failed last time? This time, thanks to advances in communication, the whole world will be watching. And American society, having gone from unimpeded exploitation of nature's bounty to the environmental movement and beyond, has changed, but has it changed enough to support politically what will be required to save this species? And are the biological problems this case presents even solvable?

Not surprisingly given its history, knowledge of the species upon which a management strategy might be based is limited, but some critical pieces of information exist. First, the species has enormous spatial requirements, estimated by Tanner (1942:33) as $16 \mathrm{~km}^{2}$ per pair. Second, it requires mature forest in order to have access to a number of large, dying but standing trees. The birds chisel away at the bark of such trees to excavate the beetle larvae that are their main source of food (Tanner 1942:40).

Caughley's (1994) declining and small population paradigms provide a useful conceptual framework for approaching species conservation. The latter refers to phenomena such as inbreeding depression and environmental stochasticity that represent threats to species persistence once populations become small, the former to a multiplicity of phenomena, such as habitat loss, persecution by humans, and exotic diseases, which cause populations to become small in the first place. Declining population phenomena can, in turn, be divided into those (such as habitat loss) that affect the "carrying capacity" of the environment for a species, and those (such as persecution and exotic diseases) that affect "vital rates" without impacting the resources a species requires.

In the United States, conservation success stories generally have involved impacts on vital rates that were corrected before small population problems became serious (Reed 1995). The recovery of Bald Eagles (Haliaeetus leucocephalus), Peregrine Falcons (Falco peregrinus), Osprey (Pandion haliaetus) and Brown Pelicans (Pelecanus occidentalis) from adverse impacts of DDT is an example. Pesticides caused the birds to produce eggs with abnormally thin shells, leading to poor hatching success; populations declined because of the resulting poor productivity. When pesticide levels were reduced, hatching success improved dramatically, and because vacant habitat was available, populations recovered (Buehler 2000; White et al. 2002; Poole et al. 2002; Shields 2002).

Carrying capacity problems are not so readily solved. The solution, providing more habitat, is no less tractable biologically than solutions to vital rates problems. Protecting land poses a more difficult political problem, however, and indeed the most politically contentious cases in the U.S. have involved carrying capacity rather than vital rates problems, Spotted Owls (Strix occidentalis) and California Gnatcatchers (Polioptila californica) being prominent examples. Habitat provided in such cases tends to be inadequate (Belovsky et al. 1994), and success in solving the problem rare (Reed 1995), the previous attempt to save the Ivory-billed Woodpecker being a case in point.

Success is easier when it is possible to enhance habitat "quality" without increasing habitat "quantity." For example, most of the preferred habitat of another North American woodpecker, the Red-cockaded Woodpecker (Picoides borealis), whose decline is caused by reduced carrying capacity (Walters 1991), is permanently gone. 
However, identification of the specific elements that are the primary determinants of carrying capacity (cavities in old, live pine trees, absence of hardwood midstory) enabled managers to stimulate population increases by providing these features in remaining habitat (Conner et al. 2001, Rudolph et al. 2004). The Ivory-billed Woodpecker case involves a similar habitat quality element, reduction of quality caused by elimination of old growth, but because of its area requirements, habitat quantity is a much larger factor than it is for Red-cockaded Woodpeckers. This combination of habitat loss and dependence of habitat quality on old growth is arguably the least tractable problem associated with the declining population paradigm.

The Ivory-billed Woodpecker's plight thus poses two major biological challenges. First, at best it exists as an extremely small population, and therefore, is highly vulnerable to every threat associated with the small population paradigm; second, it is impacted by the most intractable of declining population factors. In Caughley's (1994) framework, the first step in species conservation is to solve the problem that caused the decline. Programs in which captive-reared animals have been released into the wild (to combat small population size) without this first step being completed, e.g., the California Condor (Gymnogyps californianus) program, have been criticized for subjecting released individuals to the same fate as their wild ancestors (Meretsky et al. 2000). The Condor case involved increased mortality from lead poisoning, a vital rates problem that, at least in theory, might be solved. Solving the Ivory-billed Woodpecker's carrying capacity problem will require protection of vast amounts of mature forest, not only in Arkansas, but also, if a reasonable total population is to be achieved, in other areas with potentially suitable habitat. This could engender considerable political backlash because of conflicts with other land uses. Perhaps population densities can be increased through management of the known critical resource, feeding sites, alleviating the demand for acreage somewhat.

If enough land of suitable quality could be protected to restore a few small ( $<50$ pairs) populations, would this constitute a viable conservation strategy? Conservationists face the dilemma that, by defending the affirmative response, they risk undermining the small population paradigm that provides the rationale for conservation strategies for many other species. How this dilemma is resolved could have far-reaching implications for endangered species management, affecting distributions of conservation funds and management policy, and the credibility of conservation science. The contention that small populations are not viable is based as much on theory as on empirical data-and, especially in the policy and public domains, the persistence of the Woodpecker for the past 60 years would appear to contradict this theory. One possible solution to the dilemma is further development of small population theory from its current, general state toward a more complex and specific framework that can account for variability among species. The empirical data indicate that such variability exists: although there are myriad examples of small populations that perished in the absence of any apparent, residual, declining population factors, there are also instances of species persisting in very small numbers for long periods of time, Red-tailed Hawks (Buteo jamaicensis) on Socorro Island, for example (Walter 1990). The rediscovery of the Ivory-billed Woodpecker compels biologists to explore and explain this variability in order to defend the small population paradigm as a credible basis for conservation strategies. It compels them to demonstrate that the Ivory-billed Woodpecker possesses traits that increase ability to persist in small populations.

Those that doubt that the Ivory-billed Woodpecker can persist will question the wisdom of expending so many precious conservation dollars on a species that they consider doomed, a criticism once leveled at the California Condor program (Pitelka 1981). But Condor numbers have been greatly increased and the species returned to the wild since those criticisms were levied. Conservationists can point to similar cases in other parts of the world of bird species saved from the very brink of extinction, such as the Guam Rail (Rallus owstoni) (Haig and Ballou 1995) and several species in New Zealand, such as the Saddleback (Philesturnus carunculatus) (Hooson and Jamieson 2003) and Takahe (Porphyrio mantelli) (Lee and Jamieson 2001). But, again, the critical problem in these cases was a vital rates problem (generally impacts of exotic predators) rather than a carrying capacity problem. In New Zealand, for example, recovery has been based on translocation to islands where suitable habitat existed and predators were absent (Jamieson et al. 2003; Hooson and Jamieson 2004). No such potential refuges of abundant, suitable habitat exist for the Ivory-billed Woodpecker. 
Besides more readily addressed declining population factors, the other characteristic of successful efforts to save avian species reduced to critically small numbers is that they involve intensive management activities such as captive breeding and translocation. Use of such techniques is inconceivable in the case of the Ivory-billed Woodpecker, because of both the elusiveness and apparent shyness of the species, and the emotional reaction to the possibility that the species could be "studied to death" that is already evident. Managers likely will face similar, emotionally charged resistance from those who feel the bird should be left in peace rather than face the risk of being "managed to death."

In summary, the plight of the Ivory-billed Woodpecker presents daunting biological challenges and limited opportunity for new science to address these challenges, realities that will fuel controversies about what should be done. At the same time, biologists, conservationists, and managers are compelled to act from a sense of "restorative justice," the need to right the wrong perpetrated against the species. As there is a broad consensus, based in science, about the habitat the bird requires, focus on quality and quantity of habitat is the ideal starting point for a conservation strategy.

\section{IS A VIABLE CONSERVATION STRATEGY POSSIBLE?}

In a time when we have ceased to expect being uplifted by the news, the report that the Ivory-billed Woodpecker is not extinct has been stunning. Yet, besides triggering celebration, the report has already occasioned environmental backlash. A spokesman of a conservative think tank claims that finding this species "shows that doomsayers that preach that man and nature cannot both survive... are totally out of touch with reality" (Competitive Enterprise Institute 2005). The Arkansas birds prove, according to this logic, that nature is resilient and that our destructive impact has been overstated. Such a perspective may unfortunately carry weight in the United States today, when environmental issues seem outside the popular radar, environmentalism has been proclaimed "dead," and the exploitation of wilderness for its resources is once again being depicted as inexorable and patriotic. Whether the United States now possesses the political will that it lacked last time to preserve the species remains to be seen: already new threats to the habitat in which the bird was rediscovered loom (Koenig 2005). Other nations that struggle to protect significant areas of high quality habitat in the face of intense economic and population pressure will no doubt watch with interest how the United States fares in addressing this problem.

To preempt the political backlash that fosters complacency derived from the idea that "nature takes care of itself," two levels of response are called for. The first is promoting education about ecological and conservation issues in the public, a responsibility that lies primarily with scientists and other experts. The charisma of the Ivory-billed Woodpecker provides an opportunity for this. It is important to communicate that the discovered few individuals are no confirmation of nature's hardiness, as a small population hanging on does not a species make. Rather, a species typically comprises multiple populations found in a range of habitats to which it is adapted. A species is also defined in association with the ecosystems within which it evolved, and the bottomland hardwood (as well as upland pine) ecosystems of the Ivory-billed Woodpecker have been radically transformed. It is difficult to overstate the damage we have done to the Ivory-billed Woodpecker and its old-growth habitat - even as we can, indeed, also admire the extraordinary resilience of the species persisting despite our actions.

The second level of response called for is seizing the opportunity to pursue an inspirational vision that can work as a positive, rallying force for conservation action. The restoration of southern old-growth forest, within which Ivory-billed Woodpeckers and myriad other species flourished, can be such a vision. The bird and its habitat might serve as a rallying point for the American conservation movement to stimulate increased funding and support for environmental legislation, such as the Endangered Species Act. This will be more likely if news about the bird remains positive - how can conservation success be achieved?

Everything we know about the Ivory-billed Woodpecker indicates that protecting and expanding its habitat is a necessary condition for conservation success. Such an initiative follows a trend already in place-partly inspired by those early efforts to save the Singer tract-of the establishment of preserves, refuges, and national 
forests throughout the south. "There are several hundred thousand acres of swamp forest that are in various states, from essentially virgin to young regeneration," Jackson (2004:239) notes. "Because of their aquatic nature few are truly isolated and many are more or less linked like pearls on a string by the river systems that nurture them."

Creating an Ivory-billed Woodpecker Park, a system of interconnected wilderness areas, can build on this existing foundation. Although at this point it is hard to imagine reestablishing the species over its entire former range, we can envision stringing together bottomland river habitats to create geographically distinct, but potentially connected, populations that allow for gene flow and protect the species from location-specific stochastic threats.

Given the longstanding fascination with the Ivorybilled Woodpecker, we believe that the species has the charisma to carry such an initiative that could cross state boundaries. The states involved can use the revenue generated by visitors-birders, nature lovers, campers, and the curious-who are bound to descend in the hopes of catching a glimpse of the "Lord God bird." Visitors attracted to such a park can help support the local economies in ecologically healthy ways, and the states involved can take satisfaction in harboring a living emblem of the south. The beauty of the Ivory-billed Woodpecker's "resurrection" is not only that we get another chance to save it, but that it provides an opportunity to bring back a magnificent ecosystem with its biodiversity.

Responses to this article can be read online at: http://www.ace-eco.org/voll/iss 1/art6/responses/

\section{Acknowledgments:}

We thank the editor for encouraging us to pursue this topic; we also thank him, subject editor Doug Armstrong, and two anonymous reviewers for constructive criticism of earlier versions of the paper. We thank our colleagues at Virginia Tech, particularly Mark Barrow, for helpful discussions. We also thank the research team who made and reported the discovery of the Ivory-billed Woodpecker; their hard work made it possible to think and write about this remarkable occurrence.

\section{LITERATURE CITED}

Belovsky, G. E., J. A. Bissonette, R. D. Dueser, T. C. Edwards, Jr., C. M. Luecke, M. E. Ritchie, J. B. Slade, and F. H. Wagner. 1994. Management of small populations: concepts affecting the recovery of endangered species. Wildlife Society Bulletin 22:307316.

Buehler, D. A. 2000. Bald Eagle, Haliaeetus leucocephalus. In A. Poole and F. Gill, editors, Birds of North America. Number 506. Academy of Natural Sciences, Philadelphia, Pennsylvania, USA, and American Ornithologists' Union, Washington, D.C., USA.

Caughley, G. 1994. Directions in conservation biology. Journal of Animal Ecology 63:215-244.

Competitive Enterprise Institute. 2005. News Release. April 29, 2005. Washington, D.C., USA. (Online.) URL: www.cei.org.

Conner, R. N., D. C. Rudolph, and J. R.Walters. 2001. The Red-cockaded Woodpecker: surviving in a fire-maintained ecosystem. University of Texas Press, Austin, Texas, USA.

Fitzpatrick J. W., M. Lammertink, M. D. Luneau, Jr., T. W. Gallagher, B. R. Harrison, G. M. Sparling, K. V. Rosenberg, R. W. Rohrbaugh, E. C.H. Swarthout, P. H. Wrege, S. B. Swarthout, M. S. Dantzker, R. A. Charif, T. R. Barksdale, J. V. Remsen, Jr., S. D. Simon, and D. Zollner. 2005. Ivory Billed Woodpecker (Campephilus principalis) persists in continental North America. Science 308:1460-1462.

Haig, S. M., and J. D. Ballou. 1995. Genetic diversity in two avian species formerly endemic to Guam. Auk 112: 445-455.

Hoose, P. 2004 The race to save the Lord God bird. Melanie Kroupa Books, New York, New York, USA.

Hooson, S., and I. G. Jamieson. 2003. The distribution and current status of New Zealand Saddleback Philesturnus carunculatus. Bird Conservation International 13:79-95.

Hooson, S., and I. G. Jamieson. 2004. Variation in breeding success among reintroduced island 
populations of South Island Saddlebacks Philesturnus carunculatus carunculatus. Ibis 146:417426.

Jackson, J. 2004. In search of the Ivory-Billed Woodpecker. Smithsonian Books, Washington, D. C., USA.

Jamieson, I. G., M. S. Roy, and M. Lettink. 2003. Sex-specific consequences of recent inbreeding in an ancestrally inbred population of New Zealand Takahe. Conservation Biology 17: 708-716.

Koenig, W. D. 2005. Persistence in adversity: lessons from the Ivory-billed Woodpecker. Bioscience 55: 646-647.

Lee, W. G., and I. G. Jamieson, editors. 2001. The Takahe: fifty years of conservation management and research. University of Otago Press, Dunedin, New Zealand.

Leopold, A. 1936. Threatened species. Pages 230234 in S. L. Flader and J. Baird Calicott, editors. The river of the mother of God and other essays by Aldo Leopold. University of Wisconsin Press, Madison, Wisconsin, USA.

Meretsky, V. J., N. F. R. Snyder, S. R. Beissinger, D. A. Clendenen, and J. W. Wiley. 2000. Demography of the California Condor: implications for reestablishment. Conservation Biology 14:957967.

Pitelka, F. A. 1981. The condor case: an uphill struggle in a downhill crush. Auk 98:634-635.

Poole,A. F., R. O. Bierregaard, and M. S. Martell. 2002. Osprey, Pandion haliaetus. InA. Poole and F. Gill, editors, Birds of North America. Number 683. Academy of Natural Sciences, Philadelphia, Pennsylvania, USA, and American Ornithologists' Union, Washington, D.C., USA.

Reed, J. M. 1995. Ecosystem management and an avian habitat dilemma. Wildlife Society Bulletin 23:453-457.

Rudolph, D. C., R. N. Conner, and J. R. Walters. 2004. Red-cockaded Woodpecker recovery: an integrated strategy. Pages 70-76 in R. Costa and S. J. Daniels, editors. Red-cockaded Woodpecker: road to recovery. Hancock House Publishing, Blaine, Washington, USA.
Shields, M. 2002. Brown Pelican, Pelecanus occidentalis. In A. Poole and F. Gill, editors, Birds of North America. Number 609. Academy of Natural Sciences, Philadelphia, Pennsylvania, USA, and American Ornithologists' Union, Washington, D.C., USA.

Tanner, J. T. 1942. The Ivory-Billed Woodpecker. National Audubon Society, New York, New York, USA.

Walter, H. S. 1990. Small viable population: the Red-tailed Hawk of Socorro Island. Conservation Biology 4:441-443.

Walters, J. R. 1991. Application of ecological principles to the management of endangered species: the case of the Red-cockaded Woodpecker. Annual Review of Ecology and Systematics 22:505523.

White, C. M., N. J. Clum, T. J. Cade, and W. G. Hunt. 2002. Peregrine Falcon, Falco peregrinus. In A. Poole and F. Gill, editors, Birds of North America. Number 660. Academy of Natural Sciences, Philadelphia, Pennsylvania, USA, and American Ornithologists' Union, Washington, D. C., USA.

Wilson, A. 1840. Wilson's American ornithology. Otis, Broaders, and Company, Boston, USA. Reprinted 1970 by Arno Inc, New York, New York, USA. 